\title{
Excitation-contraction coupling and uncoupling in airway smooth muscle
}

\author{
I. W. RODGER
}

Department of Physiology and Pharmacology, University of Strathclyde, Glasgow G1 1XW, UK

\begin{abstract}
Keywords calcium ions smooth muscle excitation-contraction coupling contraction relaxation
\end{abstract}

\section{Introduction}

It is widely recognised that contraction of smooth muscle is dependent upon the concentration of free (ionised) calcium ions $\left(\mathrm{Ca}^{2+}\right)$ within the cytoplasm of the cell (Bolton, 1979; Ebashi, 1980). In the resting state the concentration of free $\mathrm{Ca}^{2+}$ within the cell is approximately $1 \times 10^{-7} \mathrm{~mol} \mathrm{l}^{-1}$ or slightly less, whereas in the extracellular fluid the $\mathrm{Ca}^{2+}$ concentration is slightly in excess of $1 \times 10^{-3} \mathrm{~mol} \mathrm{l}^{-1}$ (O'Doherty et al., 1980; Fabiato, 1981; Borle \& Snowdowne, 1982). There exists, therefore, a large inwardly directed concentration gradient down which $\mathrm{Ca}^{2+}$ can flow into the cell. At rest the cell membrane is poorly permeable to $\mathrm{Ca}^{2+}$ and consequently effectively limits to a low level the entry of the cation to the cytoplasm - the socalled passive $\mathrm{Ca}^{2+}$ leak. Such low amounts of $\mathrm{Ca}^{2+}$ entering the cell are readily dealt with by $\mathrm{Ca}^{2+}$ removal mechanisms (see below) thus contraction does not result. In contrast, upon initiation of a membrane signal, the intracellular $\mathrm{Ca}^{2+}$ concentration rises some 100 -fold from its basal level to approximately $5 \times 10^{-6}$ to $1 \times 10^{-5} \mathrm{~mol}$ $\mathrm{l}^{-1}$ (Morgan \& Morgan, 1982). This occurs as a consequence of $\mathrm{Ca}^{2+}$ arriving either from the extracellular compartment via specific $\mathrm{Ca}^{2+}$. channels opened in the cell membrane and/or released from storage sites within the cell. It is the sudden availability of these activator $\mathrm{Ca}^{2+}$ that initiates the biochemical sequences within the cell thereby effectively achieving coupling between excitation and contraction. It is the purpose of this article to briefly review this sequence of events as it relates to smooth muscle. Figure 1 summarises diagrammatically those events that will be discussed.

\section{Regulation of contractile proteins in airway smooth muscle}

The two major proteins responsible for contraction of all types of smooth muscle are actin and myosin. These proteins function by forming filaments (Adelstein \& Eisenberg, 1980; Adelstein et al., 1981). The thin filaments formed by actin are composed of two linear polymers of a 42000 dalton globular protein wrapped in the form of a helix. In contrast, myosin (thick) filaments are bipolar and composed of large molecules arranged asymmetrically. Whereas actin is composed of a single polypeptide chain, myosin is a hexamer comprising a pair of heavy chains (200 000 daltons respectively). At one end the myosin molecule is globular in shape and it is this end that possesses the enzymatic site (myosin ATPase) that hydrolyses ATP so allowing binding to actin (Adelstein \& Eisenberg, 1980). The tail portion of the myosin molecule is responsible for its assembly into bipolar filaments.

Contractile activity in smooth muscle is thought to occur via a mechanism similar to the sliding filament theory first proposed for skeletal muscle (Huxley \& Niedergerke, 1954; Huxley \& Hanson, 1954; Small \& Sobieszek, 1980). The sliding process is achieved by the attachment of the globular heads of the myosin molecules to actin, a flexing change in the conformation of the myosin head with respect to actin and then detachment of the myosin head followed by the subsequent re-attachment at another site further down the actin filament. This cyclic attachment and detachment of 'crossbridges' is driven by energy derived from ATP which is hydrolysed by myosin in response to a stimulus from actin-the so-called actin-activated myosin ATPase. When 


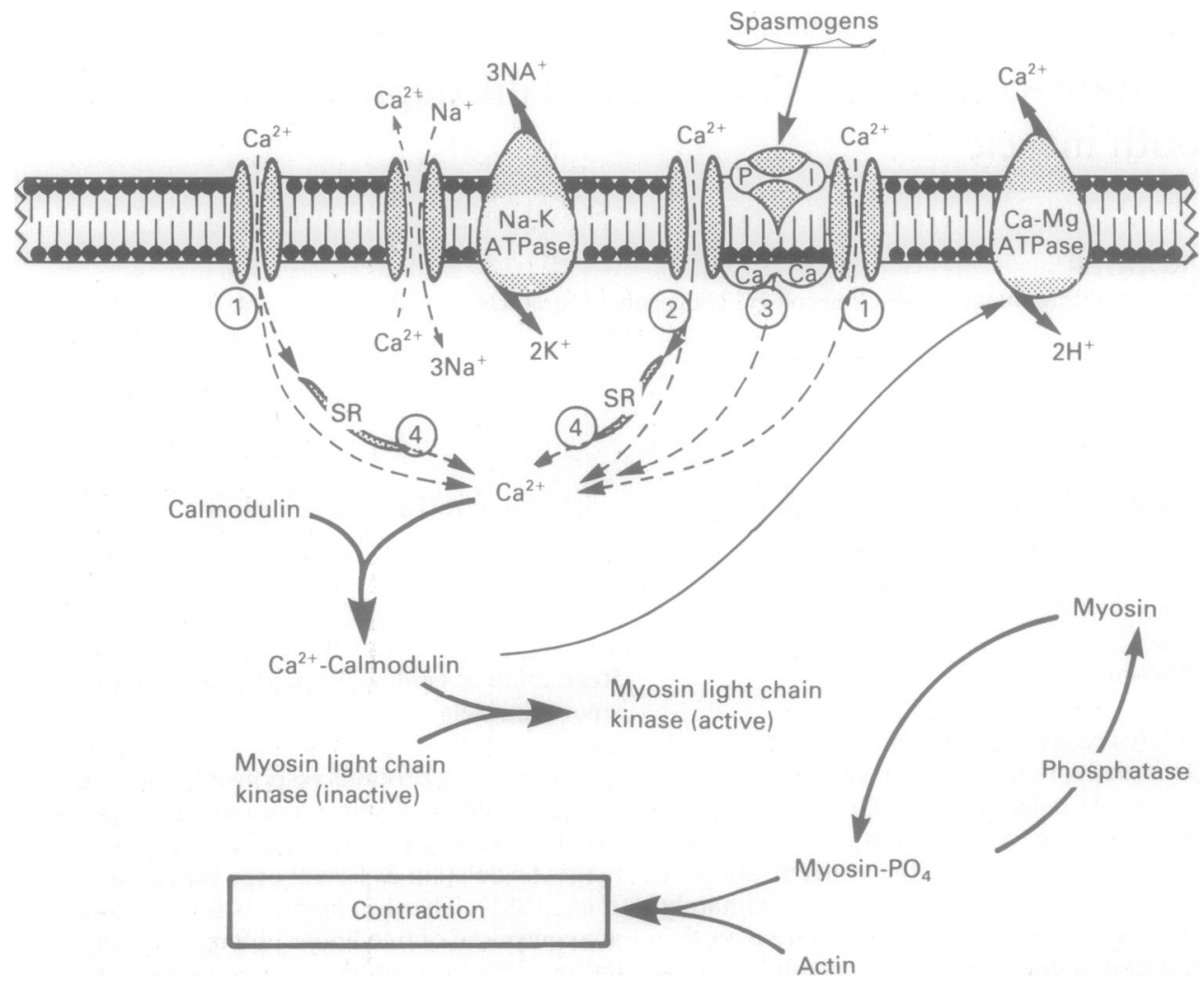

Figure 1 Diagrammatic representation of events involved in excitation-contraction coupling and cellular $\mathrm{Ca}^{2+}$ homeostasis in airway smooth muscle. $\mathrm{Ca}^{2+}$ entry to the cell from the extracellular compartment is either via voltage-dependent $\mathrm{Ca}^{2+}$ channels (VDCs; 1 ) or receptor-operated $\mathrm{Ca}^{2+}$ channels (ROCs; 2 ). Release of activator $\mathrm{Ca}^{2+}$ within the cell is from caveolae ( 3 ) and/or the sarcoplasmic reticulum (SR; 4 ) possibly mediated by a 'trigger $\mathrm{Ca}^{2+}$ ' mechanism. The combination of $\mathrm{Ca}^{2+}$ with calmodulin activates myosin light chain kinase leading to myosin phosphorylation and hence contraction. Myosin dephosphorylation occurs via a $\mathrm{Ca}^{2+}$-independent phosphatase enzyme.

Intracellular $\mathrm{Ca}^{2+}$ homeostasis is regulated by the electrogenic $\mathrm{Na}^{+} / \mathrm{Ca}^{2+}$ exchanger, which for $\mathrm{Ca}^{2+}$ efflux depends upon an inwardly directed $\mathrm{Na}^{+}$gradient, and the $\mathrm{Ca}^{2+}$-efflux pump (Ca-Mg ATPase) which can be stimulated by activated calmodulin (Ca-calmodulin complex). Spasmogens such as acetylcholine, 5 -hydroxytryptamine, histamine, leukotrienes, prostaglandins and $\alpha$-adrenoceptor agonists mediate this effect via combination with their specific receptors and opening of VDCs, ROCs or via induction of intracellular $\mathrm{Ca}^{2+}$ release. ROC opening may be controlled by the so-called PI response.

the smooth muscle cell is at rest no crossbridges are formed and the actin and myosin filaments can slide freely past each other. It is clear, therefore, that the mechanism(s) that governs the crossbridge formation regulates the activity of the contractile apparatus.

When the intracellular $\mathrm{Ca}^{2+}$ concentration reaches a critical level (about $\left.1 \times 10^{-6} \mathrm{~mol}^{-1}\right)$ it binds to calmodulin (Figure 1), a specific low molecular weight (17 000 dalton) $\mathrm{Ca}^{2+}$-binding protein that possesses four $\mathrm{Ca}^{2+}$-binding sites (Cheung, 1980; Adelstein et al., 1982; Rasmussen, 1983). The $\mathrm{Ca}^{2+}$-calmodulin complex (activated calmodulin) is then capable of combining with and initiating the biological activities of a number of different proteins, many of which are enzymes e.g. cyclic nucleotide phosphodiesterases, and sarcolemmal Ca-Mg ATPase. Another such enzyme is the 125000 dalton myosin light chain kinase which in resting smooth muscle cells exists in an inactive form (Dabrowska et al., 1977; Adelstein \& Klee, 1981). On combination with the $\mathrm{Ca}^{2+}$-calmodulin complex myosin light chain kinase becomes active and responsible for the phosphorylation of a particular serine residue located on the 20000 dalton light chains of myosin. This phosphorylation of myosin light chains is widely regarded as being a prerequisite 
for the actin activation of myosin ATPase and thus crossbridge formation (Adelstein \& Eisenberg, 1980; Stull, 1980; de Lanerolle \& Stull, 1980; de Lanerolle et al., 1982; Hartshorne \& Mrwa, 1982; Gerthoffer \& Murphy, 1983). Termination of contraction (excitation-contraction uncoupling) is associated with dephosphorylation of the myosin light chains an event achieved via a $\mathrm{Ca}^{2+}$-independent phosphatase enzyme (Figure 1).

The sequence of events outlined above and illustrated in Figure 1 is widely, although not universally, accepted. An alternative proposal (Ebashi, 1980; Nonamura \& Ebashi, 1980) suggests that myosin light chain phosphorylation is not a prerequisite for initiation of contraction of smooth muscle. These authors have also proposed that it is not calmodulin that regulates the $\mathrm{Ca}^{2+}$ sensitivity of the contractile system but the $\mathrm{Ca}^{2+}$-binding proteins leiotonins $\mathrm{A}$ and $\mathrm{C}$ which possess affinity for the actin filaments. Whatever the detailed mechanisms regulating actin/myosin interactions it is abundantly clear that the primary event responsible for triggering contraction is a rise in the concentration of activator $\mathrm{Ca}^{2+}$ in the cytoplasm of the cell.

\section{Sources of activator $\mathrm{Ca}^{2+}$ and $\mathrm{Ca}^{2+}$ movements in airway smooth muscle}

In general terms smooth muscle relies upon mobilisation of $\mathrm{Ca}^{2+}$ from both extracellular and intracellular sources to support contraction. The relative contribution of $\mathrm{Ca}^{2+}$ from these two sources to contraction, however, depends largely upon the type of smooth muscle tissue and the contractile agent in question, the concentration of the agent and the component (phasic or tonic) of the contractile response being examined (Ticku \& Triggle, 1976; Bolton, 1979). Calcium utilisation in airway smooth muscle cells has not been as extensively studied as that in vascular and intestinal smooth muscles but from the limited data available (see for example Coburn, 1977, 1979; Creese \& Denborough, 1981; Kirkpatrick, 1981; Creese, 1983; Foster et al., 1983) the above generalisations would appear to hold true at least for tracheal smooth muscle.

Activator $\mathrm{Ca}^{2+}$ from the extracellular compartment (those free in the extracellular fluid plus those bound to the external surface of the cell membrane, possibly to sialic acid residues (Ishiyama et al., 1979), gain access to the cytoplasm either via the opening of voltage-dependent $\mathrm{Ca}^{2+}$-channels (VDCs; 1 in Figure 1 ) or via receptor-operated $\mathrm{Ca}^{2+}$ channels (ROCs; 2 in Figure 1) (Bolton, 1979; Meisheri et al., 1981;
Berridge, 1982) situated in the plasmalemmal membrane. As the term implies, VDCs are opened as a consequence of certain spasmogens (including $\mathrm{K}^{+}$-depolarising solutions) interacting with their specific membrane receptors to reduce the membrane potential. In certain smooth muscles such depolarisation may generate action potentials (Bolton, 1979; Daniel et al., 1983). Tracheal smooth muscle cells, however, have a stable resting membrane potential of between $-48 \mathrm{mV}$ and $-60 \mathrm{mV}$ and action potentials are not usually observed (Kirkpatrick, 1975, 1981; Coburn \& Yamaguchi, 1977; Farley \& Miles, 1977; Coburn, 1979; Foster et al., 1983). This inability to induce action potentials has been attributed to the high membrane conductance to $\mathrm{K}^{+}$that exists in airway smooth muscle cells which effectively suppresses the regenerative increases in membrane $\mathrm{Ca}^{2+}$ conductance essential for spike firing (Kroeger \& Stephens, 1975). In place of regenerative action potentials some airway smooth muscles, for example bovine (Kirkpatrick, 1981) and guinea pig (Small, 1982; Foster et al., 1983) but not dog (Coburn \& Yamaguchi, 1977; Farley \& Miles, 1977), exhibit electrical slow-wave activity associated with contraction when depolarised with low concentrations of $\mathrm{KCl}$ (Foster et al., 1983) or tetraethylammonium (McCaig \& Souhrada, 1980; Small, 1982; Foster et al., 1984). Tetraethylammonium by virtue of inhibiting $\mathrm{K}^{+}$conductance can also, however, induce spike potentials (McCaig \& Souhrada, 1980; Small, 1982; Dixon \& Small, 1983; Foster et al., 1984), an effect not observed with $\mathrm{KCl}$-depolarising solutions. Despite the existence of such slow-wave activity it is generally accepted that, in airway smooth muscles, tension generation induced by $\mathrm{KCl}$-depolarising solutions is a consequence of graded depolarisation that opens VDCs so allowing the influx of $\mathrm{Ca}^{2+}$ from the extracellular compartment (Coburn \& Yamaguchi, 1977; Farley \& Miles, 1977; Foster et al., 1983, 1984). This mechanism is clearly demonstrated in the experiments of Coburn \& Yamaguchi (1977) where they applied hyperpolarising current to $\mathrm{KCl}$-contracted canine tracheal preparations and observed simultaneous reversal of both membrane potential and tension changes. This form of excitation-contraction coupling has been called electro-mechanical coupling (Somlyo \& Somlyo, 1968). In contrast to this type of excitation-contraction coupling ROCs can be opened as a consequence of agonistreceptor interactions, in the absence of major, detectable alterations in membrane potential. This voltage or potential independent effect has been termed pharmaco-mechanical coupling (Somlyo \& Somlyo, 1968) and is a mechanism 
that can be invoked to explain why certain agonists, for example, acetylcholine and histamine, induce contraction of tracheal smooth muscle in the presence of maximal depolarisation induced by $\mathrm{KCl}$ (Kirkpatrick, 1975). It has also been shown that the contractile response of canine tracheal muscle to acetylcholine occurs largely independently of changes in membrane potential (Farley \& Miles, 1977; Coburn, 1979). Recently attention has focussed upon the possible involvement of the so-called PI response in the gating mechanism that underlies receptor-activation of ROCs (see Figure 1; Michell, 1975; Putney, 1981, 1983; Berridge, 1982; Nishizuka, 1983). It has been suggested that some agonists that contract smooth muscle do so by inducing the conversion of phosphatidylinositol to phosphatidic acid which then functions as a $\mathrm{Ca}^{2+}$-gate. Whilst the hypothesis is an attractive one and some data exist to support the concept, other data suggest that turnover of these phospholipids, in particular phosphatidylinositol phosphates, is initiated by and not the cause of $\mathrm{Ca}^{2+}$ entry (see Daniel et al., 1983). Finally, with regard to ROCs it should be borne in mind that current fluctuations due to $\mathrm{Ca}^{2+}$ influx via these channels may lead to reductions in membrane potential which in turn could activate VDCs unless $\mathrm{Ca}^{2+}$-activated $\mathrm{K}^{+}$channels (Petersen \& Maruyama, 1984) are involved in limiting membrane potential changes. Such a possibility remains to be tested.

An additional form of pharmaco-mechanical coupling occurs where activator $\mathrm{Ca}^{2+}$ is mobilised from stores within the cell, for example from caveolae (invaginations of the internal surface of the plasmalemmal membrane; 3 in Figure 1) and from the sarcoplasmic (endoplasmic) reticulum of the cell (4 in Figure 1) despite the relative paucity of the latter (Devine et al., 1972; Bolton, 1979; Daniel et al., 1983). The release of this intracellular activator $\mathrm{Ca}^{2+}$ may involve a 'trigger' mechanism, for example $\mathrm{Ca}^{2+}$-induced $\mathrm{Ca}^{2+}$. release, similar to that proposed for skeletal (Endo, 1977) and cardiac (Fabiato \& Fabiato, 1975) muscles. In this scheme a small amount of $\mathrm{Ca}^{2+}$ entering the cell from the extracellular compartment acts to 'trigger' the release of a larger quantity of stored $\mathrm{Ca}^{2+}$ from these sites within the cell so amplifying the amount of $\mathrm{Ca}^{2+}$ available to activate contraction. The existence of such a mechanism in smooth muscle, however, remains to be established (Saida \& van Breemen, 1984).

Conclusions drawn from the electrophysiological studies in airway smooth muscles that suggest the existence of two types of $\mathrm{Ca}^{2+}$ channel are in the main supported by results from in vitro studies in which the dependence of different spasmogens upon extracellular $\mathrm{Ca}^{2+}$ concentration $\left(\left[\mathrm{Ca}^{2+}\right]_{\mathrm{o}}\right)$ have been examined. These experiments also confirm the existence of both intra- and extracellular activator $\mathrm{Ca}^{2+}$ stores and show that those spasmogens that utilise $\mathrm{Ca}^{2+}$ from the extracellular compartment are more sensitive to reductions in $\left[\mathrm{Ca}^{2+}\right]_{0}$, as one would expect. Thus in bovine, canine, guinea pig and human large airway preparations, contractions elicited by $\mathrm{KCl}$ depolarising solutions are more sensitive to reductions in $\left[\mathrm{Ca}^{2+}\right]_{0}$ than are those of 5-hydroxytryptamine, histamine, acetylcholine/methacholine and the leukotrienes $\mathrm{C}_{4}$ and $\mathrm{D}_{4}$ (Kirkpatrick, 1075; Farley \& Miles, 1978; Coburn, 1979; Creese \& Denborough, 1981; Cerrina et al., 1983; Foster et al., 1983; Weichman et al., 1983; Weiss \& Mullick, 1983; Raeburn \& Rodger, 1984).

Recent ${ }^{45} \mathrm{Ca}$ uptake studies in guinea pig tracheal smooth muscle provide further evidence for the dependence of $\mathrm{KCl}$-induced contractions upon extracellular $\mathrm{Ca}^{2+}$ (Foster et al., 1983; Raeburn \& Rodger, 1984). In contrast to $\mathrm{KCl}$, leukotriene $\mathrm{D}_{4}$ does not promote ${ }^{45} \mathrm{Ca}$ uptake into guinea pig airway smooth muscle, a result which suggests that it may utilise principally intracellular $\mathrm{Ca}^{2+}$ to initiate contraction (Raeburn \& Rodger, 1984). This finding may have important implications with regard to the treatment of asthma (see later). These ${ }^{45} \mathrm{Ca}$ uptake studies also serve to highlight one of the complications involved in in vitro preparations of large airways. It has been shown (Foster $e$ t al., 1983; Raeburn \& Rodger, 1984) that cartilage present in airway preparations takes up ${ }^{45} \mathrm{Ca}$ to a greater extent than does the smooth muscle itself. Furthermore, $\mathrm{KCl}$-depolarising solutions that stimulate ${ }^{45} \mathrm{Ca}$ uptake into airway smooth muscle devoid of cartilage cause a reduction in the lanthanum-resistant ${ }^{45} \mathrm{Ca}$ fraction in both muscle-free preparations (Foster et al., 1983) and tracheal strips containing both cartilage and muscle (Raeburn \& Rodger, 1984). In the light of such findings one should be cautious in performing $\left[\mathrm{Ca}^{2+}\right]_{0}$ depletion experiments using large airway preparations where the large reserve of $\mathrm{Ca}^{2+}$ bound to cartilage, (presumably loosely attached in that it can be liberated by $\mathrm{KCl}$ stimulation) may complicate the analysis of data.

\section{Calcium removal mechanisms}

Up to this point attention has been focussed upon $\mathrm{Ca}^{2+}$ movements in relation to contraction. As mentioned earlier, however, there exist within all smooth muscle cells, and airway smooth 
muscle is no exception, mechanisms designed to limit the rise in the intracellular free $\mathrm{Ca}^{2+}$ concentration. Essentially three mechanisms are thought to exist $; \mathrm{Na}^{+}-\mathrm{Ca}^{2+}$ exchange, uptake of $\mathrm{Ca}^{2+}$ into the sarcoplasmic reticulum and mitochondria and $\mathrm{Ca}^{2+}$ efflux from the cell (see Figure 1). Support for the existence of a $\mathrm{Na}^{+}-$ $\mathrm{Ca}^{2+}$ exchange mechanism in tracheal smooth muscle similar to that hypothesised by Reuter $e t$ al. (1973) is available (Bullock et al., 1981). This being the case then the inward movement of $\mathrm{Na}^{+}$ down its electrochemical gradient is coupled to an outward movement of $\mathrm{Ca}^{2+}$ from within the cell (Figure 1). The stoichiometry of such an exchange mechanism remains in dispute although the corpus of the evidence is that the exchange process is sensitive to alterations in membrane potential and is electrogenic in nature. This has led to the currently held view that $3 \mathrm{Na}^{+}$enter the cell for each $\mathrm{Ca}^{2+}$ that is extruded (Langer, 1983; Reeves \& Hale, 1984). Clearly the integrity of such an exchange mechanism is intimately linked to the functioning of $\mathrm{Na}^{+}-\mathrm{K}^{+}$ATPase in the plasma membrane since the controlling factor for the exchange of cations is inwardly moving $\mathrm{Na}^{+}$. One other important feature of $\mathrm{Na}^{+}-\mathrm{Ca}^{2+}$ exchange is that it is not affected by $\mathrm{Ca}^{2+}$ channel blocking drugs such as verapamil and nifedipine (see below).

The other two $\mathrm{Ca}^{2+}$ removal mechanisms are both active processes in that they derive energy from ATP hydrolysis to drive $\mathrm{Ca}^{2+}$ ions against their electrochemical gradient. The existence of a $\mathrm{Ca}^{2+}$ uptake mechanism into the sarcoplasmic reticulum (sparsely distributed as it is) and mitochondria within smooth muscle cells has been mainly sought in studies using histochemical techniques (for references see Daniel et al., 1983). As far as airway smooth muscle is concerned no direct evidence is available to substantiate the existence of such an uptake process into the sarcoplasmic reticulum. However, since microsomal fractions of airway smooth muscle (mostly mixed preparations containing particulate material enriched in plasma membrane and sarcoplasmic reticulum) have been shown to accumulate $\mathrm{Ca}^{2+}$ via an ATP-dependent uptake process (Sands \& Mascali, 1978; Hogaboom \& Fedan, 1981) it is likely that the sarcoplasmic reticulum does have a role to play in the sequestration of activator $\mathrm{Ca}^{2+}$. Mitochondria, on the other hand, are not thought to play a major role in the regulation of intracellular $\mathrm{Ca}^{2+}$ concentration in most smooth muscles under normal physiological conditions (Rasmussen, 1983) but may be important when intracellular $\mathrm{Ca}^{2+}$ concentration is increased well above normal, for example in pathological conditions (Daniel et al., 1983).
The $\mathrm{Ca}^{2+}$ efflux pump (Ca-Mg ATPase) was first discovered in the erythrocyte cell membrane (Schatzmann, 1966; Schatzmann \& Vincenzi, 1969) and most of the characterisation of the enzymatic process has been performed using this tissue (for references see Rasmussen, 1983). A closely similar enzyme, however, has been shown to be present in the plasma membrane of most cells including smooth muscle (Daniel et al., 1983; Rasmussen, 1983). The pump is thought to operate as an electro-neutral exchanger whereby each $\mathrm{Ca}^{2+}$ extruded from the cell is counterbalanced by the inward movement of $2 \mathrm{H}^{+}$(Niggli et al., 1982). Any significant alteration in intracellular $\mathrm{pH}$ consequent upon the entry of $\mathrm{H}^{+}$is negated by the accompanying inward movement of $\mathrm{OH}^{-}$which is electroneutrally exchanged for $\mathrm{Cl}^{-}, \mathrm{HPO}_{4}{ }^{=}$or $\mathrm{HCO}_{3}{ }^{-}$. In microsomes of airway smooth muscle, as well as in red cells, the $\mathrm{Ca}^{2+}$ efflux pump can be stimulated by activated calmodulin $\left(\mathrm{Ca}^{2+}-\right.$ calmodulin complex; see Figure 1) thus it may function automatically to offset any rise in intracellular $\mathrm{Ca}^{2+}$ resulting from a triggering stimulus (Hogaboom \& Fedan, 1981; Vincenzi et al., 1980; Waisman et al., 1981; Rasmussen, 1983). Furthermore, the fact that the $K_{\mathrm{m}}\left(\mathrm{Ca}^{2+}\right)$ for the pump lies in the range $1.5 \times 10^{-7} \mathrm{~mol} \mathrm{l}^{-1}$ to $4.5 \times$ $10^{-7} \mathrm{~mol} \mathrm{l}^{-1}$ means that it is ideally suited, in conjunction with the $\mathrm{Na}^{+} / \mathrm{Ca}^{2+}$ exchanger, to maintain the intracellular $\mathrm{Ca}^{2+}$ concentration of resting cells at less than $1 \times 10^{-7} \mathrm{~mol} \mathrm{l}^{-1}$. The activity of the pump in some smooth muscles may also be augmented by cyclic AMP acting via its dependent protein kinases (for references see Daniel et al., 1983). In the only study using airway tissue, however, Sands \& Mascali (1978) have reported that the opposite effect-a reduction in $\mathrm{Ca}^{2+}$ uptake-occurs in bovine tracheal microsomes. It is patently obvious that many more studies using purer preparations of both plasma membranes and protein kinases are required in order to characterise the $\mathrm{Ca}^{2+}$ pump in smooth muscle. Based upon the evidence available at present in other smooth muscles it is unreasonable, on the basis of a single study, to reject the concept that in airway smooth muscle the $\mathrm{Ca}^{2+}$-efflux pump is stimulated by a cyclic AMP-dependent mechanism.

\section{Drug-induced modification of excitation- contraction coupling}

In preventing/alleviating the bronchospasm associated with asthma the essential requirement (as outlined above) is to control and minimise the amount of activator $\mathrm{Ca}^{2+}$ within the 
cytoplasm of the cell. This could be achieved in several ways: 1 . Inhibition of transmembrane influx of $\mathrm{Ca}^{2+}$ from the extracellular compartment: 2. Inhibition in intracellular $\mathrm{Ca}^{2+}$ release; 3. Inhibition of calmodulin activation; 4. Augmentation of $\mathrm{Ca}^{2+}$ removal processes; 5. Inhibition of the biochemical sequences leading to interaction of actin and myosin. In this concluding section attention will be focussed briefly upon two categories of bronchodilator drugs that may exert their effects via certain of the above mechanisms-the so-called $\mathrm{Ca}^{2+}$-channel blocking drugs and those drugs thought to act via cyclic AMP-dependent mechanisms (Figure 2).

The $\mathrm{Ca}^{2+}$-channel blocking drugs such as verapamil, diltiazem and the dihydropyridine group of compounds exemplified by nifedipine have for some time been used safely in the treatment of a variety of cardiovascular disorders. Recently, attention has focussed upon the potential use of such compounds to uncouple excitationcontraction processes in asthma (McFadden, 1981; Triggle, 1983). However, with the possible exception of exercise-induced asthma there is little convincing evidence either in vitro or in vivo that these $\mathrm{Ca}^{2+}$-channel blocking drugs inhibit bronchoconstriction induced by a wide variety of different spasmogens at other than high concentrations (for references see Barnes, 1983; Raeburn \& Rodger, 1984). One possible explanation for this lack of effect is that in asthma the chemical mediators involved induce the influx of activator $\mathrm{Ca}^{2+}$ from the extracellular compartment via receptor-operated channels

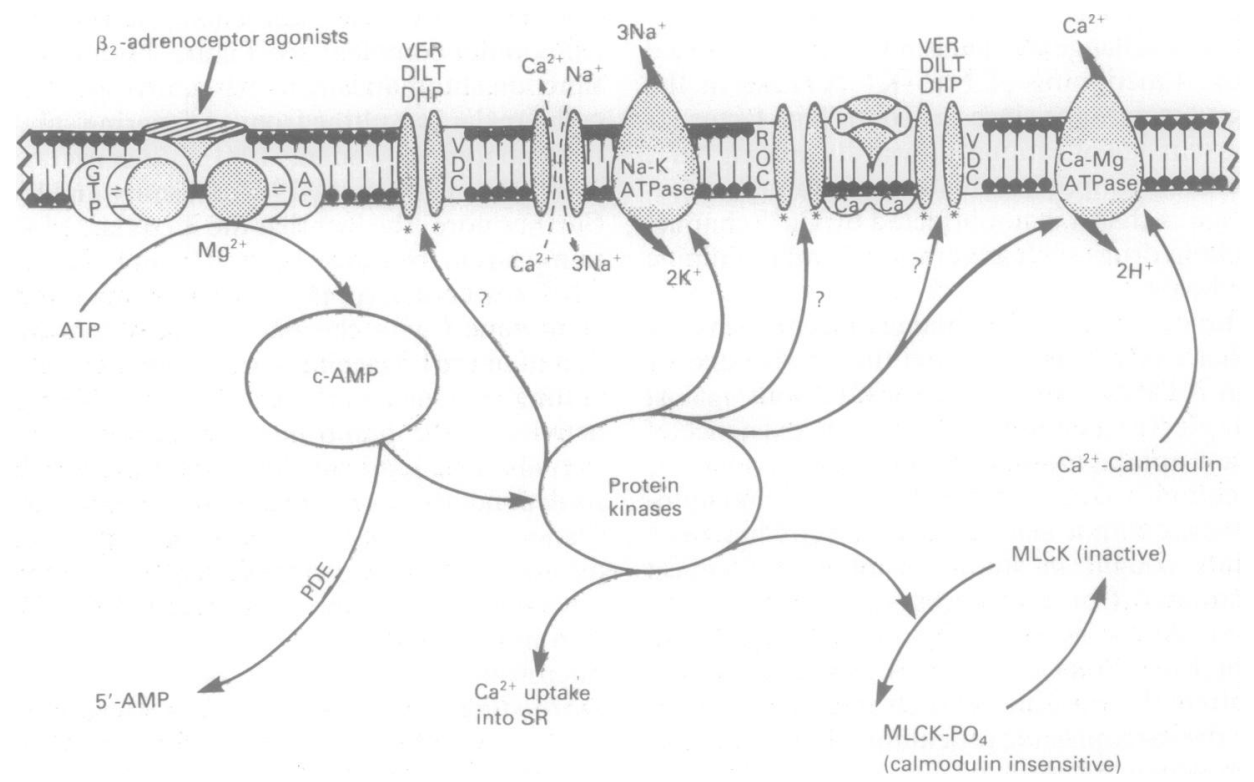

Figure 2 Diagrammatic representation of mechanisms whereby excitation-contraction uncoupling may be achieved by calcium channel blocking drugs and those drugs thought to operate via cyclic AMPdependent processes e.g. $\boldsymbol{\beta}_{2}$-adrenoceptor agonists (rimiterol, salbutamol, terbutaline) and phosphodiesterase (PDE) inhibitors (aminophylline, theophylline).

Voltage-dependent $\mathrm{Ca}^{2+}$ channels (VDC) may be blocked by verapamil (VER), diltiazem (DILT) or dihydropyridine compounds (DHP) such as nifedipine and nitrendipine. These compounds are not thought to exert a significant effect on ROCs.

$\beta_{2}$-adrenoceptor agonists in concert with the GTP-dependent guanine nucleotide regulatory proteins in the cell membrane activate adenylate cyclase (AC) to catalyse the conversion of ATP to cyclic AMP within the cell. Phosphodiesterase inhibitors increase cyclic AMP by preventing its enzymatic degradation to 5'-AMP. Specific protein kinases activated by cyclic AMP are capable of augmenting the uptake of $\mathrm{Ca}^{2+}$ by the sarcoplasmic reticulum (SR), downgrading the activity of myosin light chain kinase (MLCK) by phosphorylating it and making it calmodulin insensitive, stimulating the $\mathrm{Ca}-\mathrm{Mg} \mathrm{ATPase}$ to enhance $\mathrm{Ca}^{2+}$ extrusion from the cell and stimulating the sodium pump (Na-K ATPase) so augmenting $\mathrm{Ca}^{2+}$ removal via the $\mathrm{Na} / \mathrm{Ca}$ exchanger. Cyclic AMP-dependent protein kinases may also reduce membrane $\mathrm{Ca}^{2+}$ conductance by phosphorylating specific proteins associated with the $\mathrm{Ca}^{2+}$ channels. 
which would be relatively unaffected by the currently available $\mathrm{Ca}^{2+}$-channel blocking drugs, all of which exert a preferential effect on the voltage-dependent $\mathrm{Ca}^{2+}$ channel (see Figure 2).

Alternatively, the chemical mediators of asthma may utilise principally $\mathrm{Ca}^{2+}$ from an intracellular source to initiate contraction. The recent observation of Raeburn \& Rodger (1984) that leukotriene $\mathrm{D}_{4}$ does not stimulate ${ }^{45} \mathrm{Ca}$ uptake into guinea pig tracheal smooth muscle is consistent with this latter suggestion. Thus at the present time there is little convincing evidence in favour of the use of VDC blocking drugs in airway disorders such as asthma. Given the present state of knowledge it would seem that only with the advent of ROC blocking drugs will inhibition of transmembrane $\mathrm{Ca}^{2+}$ influx be an effective means of preventing/alleviating bronchospasm.

In stark contrast to the ineffectiveness of the VDC channel blocking drugs $\boldsymbol{\beta}_{2}$-adrenoceptor agonists (e.g. salbutamol, terbutaline and rimiterol) and phosphodiesterase inhibiting drugs (aminophylline, theophylline) provide the mainstay in the treatment of asthma. It is well recognised that $\beta_{2}$-adrenoceptor agonists, in concert with the guanine nucleotide regulatory protein, activate the enzyme adenylate cyclase and so convert ATP to cyclic AMP. (For a review of events as they relate to smooth muscle see Krall et al., 1983; Kroeger, 1983.) Elevated cyclic AMP levels within many smooth muscles including lung tissue are associated with relaxation (Vulliemoz et al., 1977; Krall et al., 1983; Kroeger, 1983) although a direct cause and effect relationship between the two events has not been unequivocally demonstrated. In airway smooth muscle cyclic AMP-dependent protein kinase activity is increased following $\beta$-adrenoceptor stimulation (Torphy et al., 1982). These activated protein kinases, in turn, are capable of modifying several of the processes involved in the excitation-contraction coupling and uncoupling sequences described earlier (see Figure 2). In this way, therefore, drugs that elevate

\section{References}

Adelstein, R. S. (1983). Regulation of contractile proteins by phosphorylation. J. clin. Invest., 72, 1863-1866.

Adelstein, R. S., de Lanerolle, P., Sellers, J. R., Pato, M. D. \& Conti, M. A. (1982). Regulation of contractile proteins in smooth muscle and platelets by calmodulin and cyclic AMP. In Calmodulin and intracellular $\mathrm{Ca}^{2+}$ receptors, eds Kakiuchi, S., Hidaka, H. \& Means, R., pp 313-331. New York: Plenum Press.

Adelstein, R. S. \& Eisenberg, E. (1980). Regulation cyclic AMP may augment the uptake of activator $\mathrm{Ca}^{2+}$ into the sarcoplasmic reticulum and/or its extrusion via the Ca-Mg ATPase pump in the plasma membrane (Daniel et al., 1983; Kroeger, 1983) and in so doing reduce the level of activator $\mathrm{Ca}^{2+}$ within the cell. Stimulation of the plasmalemmal $\mathrm{Na}-\mathrm{K}$ ATPase enzyme by cyclic AMP-dependent protein kinases could also contribute to $\mathrm{Ca}^{2+}$ efflux via the $\mathrm{Na} / \mathrm{Ca}$ exchange mechanism by enhancing the inwardly directed $\mathrm{Na}^{+}$gradient (Scheid et al., 1979; Kroeger, 1983). Recently, much interest has centred upon the ability of cyclic AMP to induce the phosphorylation of the enzyme myosin light chain kinase that is regarded as an integral part in the contractile sequence (see earlier). Phosphorylation of myosin light chain kinase reduces its sensitivity to calmodulin and effectively downgrades the activity of the enzyme thus impeding the pathway to myosin phosphorylation and hence contraction (Adelstein \& Hathaway, 1979; Adelstein et al., 1982; Adelstein, 1983). This represents an interesting means of inducing relaxation independent of the removal of activator $\mathrm{Ca}^{2+}$. The importance of such a mechanism in mediating bronchodilatation has, however, recently been questioned (Miller et al., 1983).

Finally, it is interesting to speculate that cyclic AMP-dependent protein kinases may inhibit membrane $\mathrm{Ca}^{2+}$ conductance via phosphorylation of phosphoproteins that are an integral part of the $\mathrm{Ca}^{2+}$ channels (Figure 2). Were this indeed to be the case it would represent the converse event of that established in cardiac muscle where phosphorylation of calciductin mediates an increase in $\mathrm{Ca}^{2+}$ entry to the myocardium via an enhancement of the probability of VDC opening (Haiech \& Demaille, 1983; Tsien, 1983; Bowman et al., 1985).

The author's work referred to in this article was supported by grants from the Asthma Research Council, Wellcome Trust and Pharmaceutical Society of Great Britain. and kinetics of the actin-myosin-ATP interaction. Ann. Rev. Biochem., 49, 921-956.

Adelstein, R. S. \& Hathaway, D. R. (1979). Role of calcium and cyclic adenosine $3^{\prime}, 5^{\prime}$-monophosphate in regulating smooth muscle contraction. Mechanisms of excitation-contraction coupling in smooth muscle. Am. J. Cardiol., 44, 783-787.

Adelstein, R. S. \& Klee, C. B. (1981). Purification and characterisation of smooth muscle myosin light chain kinase. J. biol. Chem., 256, 7501-7509.

Adelstein, R. S., Pato, M. D. \& Conti, M. A. (1981). 
The role of phosphorylation in regulating contractile proteins. Adv. Cyclic Nucl. Res., 14, 361-373,

Barnes, P. J. (1983). Calcium channel blockers and asthma. Thorax, 38, 481-485.

Berridge, M. J. (1982). Regulation of cell secretion: the integrated action of cyclic AMP and calcium. In Cyclic nucleotides II, Physiology and pharmacology, Handbook of experimental pharmacology Vol. 58 (II), eds Kebabian, J. W. \& Nathanson, J. A., pp 227-270. Berlin: Springer-Verlag.

Bolton, T. B. (1979). Mechanisms of action of transmitters and other substances on smooth muscle. Physiol. Rev., 59, 606-718.

Borle, A. B. \& Snowdowne, K. W. (1982). Measurement of intracellular free calcium in monkey kidney cells with aequorin. Science, 217, 252-254.

Bowman, W. C., Rodger, I. W. \& Shahid, M. (1985). Modification of calcium ion exchange and its relation to myocardial contractility. In Control and manipulation of calcium movement, ed Parratt, J. R., pp 213-238. New York: Raven Press.

Bullock, C. G., Fettes, J. J. F. \& Kirkpatrick, C. T. (1981). Tracheal smooth muscle- - second thoughts on sodium-calcium exchange: J. Physiol., 318, 46.

Cerrina, J., Advenier, C., Renier, A., Floch, A. \& Duroux, P. (1983). Effects of diltiazem and other $\mathrm{Ca}^{2+}$ antagonists on guinea pig tracheal muscle. Eur. J. Pharmac., 94, 241-249.

Cheung, W. Y. (1980). Calmodulin plays a pivotal role in cellular regulation. Science, 207, 19-27.

Coburn, R. F. (1977). The airway smooth muscle cell. Fed. Proc., 36, 2692-2697.

Coburn, R. F. (1979). Electromechanical coupling in canine trachealis muscle: acetylcholine contractions. Am. J. Physiol., 236, C177-C184.

Coburn, R. F. \& Yamaguchi, T. (1977). Membrane potential-dependent and -independent tension in the canine tracheal muscle. J. Pharmac. exp. Ther., 201, 276-284.

Creese, B. R. (1983). Calcium ions, drug action and airways obstruction. Pharmac. Ther., 20, 357-375.

Creese, B. R. \& Denborough, M. A. (1981). Sources of calcium for contraction of guinea-pig isolated tracheal smooth muscle. Clin. exp. Pharmac. Physiol., 8, 175-182.

Dabrowska, R., Aromatoria, D., Sherry, J. M. F. \& Hartshorne, D. J. (1977). Composition of the myosin light chain kinase from chicken gizzard. Biochim. Biophys. Res. Comm., 78, 1263-1272.

Daniel, E. E., Grover, A. K. \& Kwan, C. Y. (1983). Calcium. In Biochemistry of smooth muscle. Vol III, ed. Stephens, N. L., pp 1-88. Boca Raton, Florida: CRC Press Inc.

de Lanerolle, P., Condit, J. R., Tanenbaum, M. \& Adelstein, R. S. (1982). Myosin phosphorylation, agonist concentration and contraction of tracheal smooth muscle. Nature, 298, 871-872.

de Lanerolle, P. \& Stull, J. T. (1980). Myosin phosphorylation during contraction and relaxation of tracheal smooth muscle. J. biol. Chem., 255, 9993-10000.

Devine, C. E., Somlyo, A. V. \& Somlyo, A. P. (1972). Sarcoplasmic reticulum and excitation-contraction coupling in mammalian smooth muscles. J. cell Biol., 52, 690-718.
Dixon, J. S. \& Small, R. C. (1983). Evidence of poor conduction of muscle excitation in the longitudinal axis of guinea-pig isolated trachea. $B r . J$. Pharmac., 79, 75-83.

Ebashi, S. (1980). Regulation of muscle contraction. Proc. Roy. Soc., Lond. B., 207, 259-286.

Endo, M. (1977). Calcium release from the sarcoplasmic reticulum. Physiol. Rev., 57, 71-108.

Fabiato, A. (1981). Myoplasmic free calcium concentration reached during the twitch of an intact isolated cardiac cell and during calcium-induced release of calcium from the sarcoplasmic reticulum of a skinned cardiac cell from the adult rat or rabbit ventricle. $J$. gen. Physiol., 78, 457-497.

Fabiato, A. \& Fabiato, F. (1975). Contractions induced by a calcium-triggered release of calcium from the sarcoplasmic reticulum of single skinned cardiac cells. J. Physiol., 249, 469-495.

Farley, J. M. \& Miles, P. R. (1977). Role of depolarisation in acetylcholine-induced contractions of dog trachealis muscle. J. Pharmac. exp. Ther., 201, 199-205.

Farley, J. M. \& Miles, P. R. (1978). The sources of calcium for acetylcholine-induced contractions of dog tracheal smooth muscle. J. Pharmac. exp. Ther., 207, 340-346.

Foster, R. W., Okpalugo, B. I. \& Small, R. C. (1984). Antagonism of $\mathrm{Ca}^{2+}$ and other actions of verapamil in guinea-pig isolated trachealis. Br. J. Pharmac., 81, 499-507.

Foster, R. W., Small, R. C. \& Weston, A. H. (1983). The spasmogenic action of potassium chloride in guinea-pig trachealis. Br. J. Pharmac., 80, 553-559.

Gerthoffer, W. T. \& Murphy, R. A. (1983). Myosin phosphorylation and regulation of cross-bridge cycle in tracheal smooth muscle. Am. J. Physiol., 244, C182-C187.

Haiech, J. \& Demaille, J. G. (1983). Phosphorylation and the control of calcium fluxes. Philos. Trans. $R$. Soc. Lond. B., 302, 91-98.

Hartshorne, D. J. \& Mrwa, U. (1982). Regulation of smooth muscle actomyosin. Blood Vessels, 19, 1-18.

Hogaboom, G. K. \& Fedan, J. S. (1981). Calmodulin stimulation of calcium uptake and $\left(\mathrm{Ca}^{2+}-\mathrm{Mg}^{2+}\right)$ ATPase activities in microsomes from canine tracheal smooth muscle. Biochem. Biophys. Res. Comm., 99, 737-744.

Huxley, A. F. \& Niedergerke, R. (1954). Structural changes in muscle during contraction. Interference microscopy of living muscle fibres. Nature, 173, 971-973.

Huxley, H. \& Hanson, J. (1954). Changes in the crossstriations of muscle during contraction and stretch and their structural interpretation. Nature, 173, 973-976.

Ishiyama, Y. Yabu, H. \& Miyazaki, E. (1975). Changes in contractility and calcium binding of guinea pig Taenia Coli by treatment with enzymes which hydrolyse sialic acid. Jap. J. Physiol., 25, 719-727.

Kirkpatrick, C. T. (1975). Excitation and contraction in bovine tracheal smooth muscle. J. Physiol., 244, 263-281.

Kirkpatrick, C. T. (1981). Tracheobronchial smooth muscle. In Smooth muscle: an assessment of current 
knowledge, eds Bulbring, E., Brading, A. F., Jones, A. W. \& Tomita, T., pp 385-395. London: Edward Arnold.

Krall, J. F., Fortier, M. \& Korenman, S. G. (1983). Smooth muscle cyclic nucleotide biochemistry. In Biochemistry of smooth muscle, Vol. III, ed. Stephens, N. L., pp 89-128. Boca Raton, Florida: CRC Press.

Kroeger, E. A. (1983). Role of cyclic nucleotides in modulating smooth muscle function. In Biochemistry of smooth muscle, Vol. III, ed Stephens, N. L. pp 129-139. Boca Raton, Florida: CRC Press.

Kroeger, E. A. \& Stephens, N. L. (1975). Effect of tetraethylammonium on tonic airway smooth muscle: initiation of phasic electrical activity. Am. J. Physiol., 228, 633-636.

Langer, G. A. (1983). The 'sodium pump lag' revisited. J. mol. cell. Cardiol., 15, 647-651.

McCaig, D. J. \& Souhrada, J. F. (1980). Alteration of electrophysiological properties of airway smooth muscle from sensitised guinea pigs. Resp. Physiol., 41, 49-60.

McFadden, E. R. (1981). Calcium channel blocking agents and asthma. Ann. Intern. Med., 95, 232-233.

Meisheri, K., Hwang, O. \& van Breemen, C. (1981). Evidence for two separate $\mathrm{Ca}^{2+}$ pathways in smooth muscle plasmalemma. J. memb. Biol., 59, 19-25.

Michell, R. H. (1975). Inositol phospholipids and cell surface receptor function. Biochim. Biophys. Acta, 415, 81-147.

Miller, J. R., Silver, P. J. \& Stull, J. T. (1983). The role of myosin light chain kinase phosphorylation in beta-adrenergic relaxation of tracheal smooth muscle. Mol. Pharmac., 24, 235-242.

Morgan, J. P. \& Morgan, K. G. (1982). Vascular smooth muscle; the first recorded $\mathrm{Ca}^{2+}$ transients. Pflueger's Archiv., 395, 75-77.

Niggli, V., Sigel, E. \& Carafoli, E. (1982). The purified $\mathrm{Ca}^{2+}$ pump of human erythrocyte membranes catalyzes an electroneutral $\mathrm{Ca}^{2+}-\mathrm{H}^{+}$exchange in reconstituted lysosomal systems. J. biol. Chem., 257, 2350-2356.

Nishizuka, Y. (1983). Calcium, phospholipid turnover and transmembrane signalling. Phiios. Trans. $R$. Soc. Lond. B., 302, 101-112.

Nonamura, Y. \& Ebashi, S. (1980). Calcium regulatory mechanism in vertebrate smooth muscle. Biomed. Res., 1, 1-14.

O'Doherty, J., Youmans, S. J., Armstrong, W. McD. \& Stark, R. J. (1980). Calcium regulation during stimulus secretion coupling: continuous measurement of intracellular calcium activities. Science, 209, 510-513.

Petersen, O. H. \& Maruyama, Y. (1984). Calciumactivated potassium channels and their role in secretion. Nature, 307, 693-696.

Putney, J. W. (1981). Recent hypotheses regarding the phosphatidylinositol effect. Life Sci., 29, 11831194.

Putney, J. W. (1983). Phosphatidylinositol metabolism and $\alpha$-adrenoceptor mechanisms. In Adrenoceptors and catecholamine action, Part $B$, ed. Kunos, G., pp 51-64. New York: John Wiley \& Sons.
Raeburn, D. \& Rodger, I. W. (1984). Lack of effect of leukotriene $\mathrm{D}_{4}$ on ${ }^{45} \mathrm{Ca}$ uptake in airway smooth muscle. Br. J. Pharmac., 83, 499-504.

Rasmussen, H. (1983). Pathways of amplitude and sensitivity modulation in the calcium messenger system. In Cell and cell function, Vol. IV, pp 1-61. New York: Academic Press Inc.

Reeves, J. P. \& Hale, C. C. (1984). The stoichiometry of the cardiac $\mathrm{Na}^{+} / \mathrm{Ca}^{2+}$ exchange system. J. biol. Chem., 259, 7733-7739.

Reuter, H., Blaustein, M. P. \& Haeusler, G. (1973). $\mathrm{Na}-\mathrm{Ca}$ exchange and tension development in arterial smooth muscle. Philos. Trans. 2 . Soc. Lond. B., 265, 87-94.

Saida, K. \& van Breemen, C. (1984). Characteristics of the norepinephrine-sensitive $\mathrm{Ca}^{2+}$ store in vascular smooth muscle. Blood Vessels, 21, 43-52.

Sands, H., Mascali, J. (1978). Effects of cyclic AMP and of protein kinase on the calcium uptake by various tracheal smooth muscle organelles. Arch. int. Pharmacodyn. Ther., 236, 180-191.

Schatzmann, H. J. (1966). ATP-dependent $\mathrm{Ca}^{2+}$ extrusion from human red cells. J. Physiol., 235, 551569.

Schatzmann, H. J. \& Vincenzi, F. F. (1969). Calcium movements across the membranes of human red cells. J. Physiol., 201, 369-395.

Scheid, C. R., Honeym:an, T. W. \& Fay, F. S. (1979). Mechanism of $\beta$-adrenergic relaxation of smooth muscle. Nature, 277, 32-36.

Small, J. V. \& Sobieszek, A. (1980). The contractile apparatus of smooth muscle. Int. Rev. Cytol., 64, 1-79.

Small, R. C. (1982). Electrical slow waves and tone of guinea pig isolated trachealis muscle: the effects of drugs and temperature changes. Br. J. Pharmac., 77, 45-54.

Somlyo, A. V. \& Somlyo, A. P. (1968). Electromechanical and pharmacomechanical coupling in vascular smooth muscle. J. Pharmac. exp. Ther., 159, 129-145.

Stull, J. T. (1980). Phosphorylation of contractile proteins in relation to muscle function. Adv. Cyclic Nucl. Res., 13, 39-93.

Ticku, M. K. \& Triggle, D. J. (1976). Calcium and the muscarinic receptor. Gen. Pharmac., 7, 133-140.

Torphy, T. J., Freese, W. B., Rinard, G. A., Brunton, L. L. \& Mayer, S. E. (1982). Cyclic nucleotidedependent protein kinases in airway smooth muscle. J. biol. Chem., 257, 11609-11616.

Triggle, D. J. (1983). Calcium, the control of smooth muscle function and bronchial hyperreactivity. Allergy, 38, 1-9.

Tsien, R. W. (1983). Calcium channels in excitable cell membranes. Ann. Rev. Physiol., 45, 341-358.

Vicenzi, F. F., Hines, T. R. \& Raess, B. V. (1980). Calmodulin and the plasma membrane calcium pump. Ann. N. Y. Acad. Sci., 256, 233-244.

Vulliemoz, Y., Verosky, M. \& Triner, L. (1977). The cyclic adenosine $3^{\prime}, 5^{\prime}$-monophosphate system in bronchial tissue. In Biochemistry of smooth muscle, ed Stephens, N. L. pp 293-314. Baltimore: University Park Press.

Waisman, D. M., Gimble, J., Goodman, D. B. P. \& Rasmussen, H. (1981). Studies of the $\mathrm{Ca}^{2+}$ trans- 
port mechanism of human inside-out plasma membrane vesicles. I. Regulation of the $\mathrm{Ca}^{2+}$ pump by calmodulin. J. biol. Chem., 256, 409-414.

Weichman, B. M. Muccitelli, R. M., Tucker, S. S. \& Wasserman, M. A. (1983). Effect of calcium antagonists on leukotriene $\mathrm{D}_{4}$-induced contractions of the guinea pig trachea and lung parenchyma. J. Pharmac. exp. Ther., 225, 310-315.

Weiss, E. B. \& Mullick, P. C. (1983). Leukotriene effect in airways smooth muscle: calcium dependency and verapamil inhibition. Prostaglandins, Leukotrienes Med., 12, 53-66.

\section{Discussion}

Barnes In both human and guinea pig airway smooth muscle calcium channel blockers are not very potent at preventing the contraction induced by histamine, but potently reverse contraction induced by histamine. Nifedipine, is active in concentrations of $10^{-8} \mathrm{M}$, i.e. therapeutically relevant concentrations. Have you any explanation for this, because it has clinical implications; whereas in the past we have designed clinical trials to look at the preventative effects of calcium blockers we might find that they have greater potency in reversing induced bronchoconstriction.

Skidmore Does the concentration of intracellular calcium required to induce contraction in airway smooth muscle differ from that necessary to maintain contraction once this is produced?

Rodger When we are talking about voltagedependent mechanisms, a hyperpolarising current reverses both membrane changes and contraction, indicating that the two events are tightly coupled and that through voltage coupling calcium has to be continuously presented to the tissue for contraction. It might be different for intracellular calcium release, since this calcium comes from a variety of sources and the rates at which calcium is presented to calmodulin will depend on its source. The relationships of calcium movements within a cell have not been mapped out however.

Small Using aequorin in smooth muscle, a different amount of tension develops for a certain change in free intracellular calcium when different agonists are used. There is a differentiation between the rise in intracellular calcium and the amount of tension obtained.

Towart Nifedipine is quite potent at relaxing the contraction which has developed to either leukotrienes or histamine when added during the contraction. This suggests that the initial stage of contraction involves release of intracellular calcium which is less affected, and that at a later stage there is an influx of calcium from the exterior to maintain contraction (Peck et al., 1984) (Figure 3). However, others have shown that, with cumulative dose-response curves to spasmogens, calcium antagonists have no effect.

Barnes It is difficult to understand this discrepancy as some studies show that contraction is reversed by calcium channel blockers, whereas others show that it is not.

Rodger We find that if we do our experiments the way Dr Towart does we get the same effect, but then if we follow the protocol of Weichmann et al. (1983), we can also reproduce their findings. There is some difference in the methodology.

Small You can see both phenomena in the same experiment. If a cumulative dose response curve to acetylcholine or histamine is performed and one concentration selected, a calcium antagonist has some spasmolytic effect. If the calcium antagonist is retained but the agonist removed, then reconstruction of the agonist cumulative dose response curve shows it to be similar to the control curve.

Towart Which is more relevant to asthma and bronchial hyperreactivity: a dose-response curve or a single administration of spasmogen?

B. Richardson An agonist may let calcium into the cell in different ways, depending on how it is contracted. For example, once the contraction is established, leukotrienes may prefer to open VSCs, but if you put in a calcium antagonist, then it can switch over to transporting calcium via ROCs. The VSC and ROC may be one and the same thing but exist in two conformational states.

Barnes Do you have any evidence for that?

B. Richardson In an experiment with lung parenchyma we found that $\mathrm{LTC}_{4}$-induced contractions were sensitive to a dihydropyridine calcium antagonist (PY 108-068), providing the membrane was in a polarised state. If the membrane is depolarised before adding $\mathrm{LTC}_{4}$, a contraction to the agonist ensues but it is not sensitive to PY 108-068.

Barnes Are there two anatomically distinct channels, or one channel opened in different ways? This is of great importance in the design of 